\title{
Making the Single Market
}

\author{
Witness Remarks
}

Stephen WALL

As early as 1982, Margaret Thatcher reported to the House of Commons that she had, at a meeting of the European Council, stressed to her fellow Heads of Government the vital need to complete the single market in services. ${ }^{1}$

The European Council in Fontainebleau in June 1984 was most notable for its resolution of the long and bloody battle over the British EU budget contribution. But at that meeting Thatcher also gave to her fellow leaders a booklet, drafted in the British Cabinet Office and Foreign Office. Although it was not written by Thatcher, she had read it and approved it which, in her case, invariably meant reading every word. "We must" said the pamphlet

"create the genuine common market in goods and services which is envisaged in the Treaty of Rome and will be crucial to our ability to meet the US and Japanese technological challenge. Only by a sustained effort to removing remaining obstacles to intra-Community trade can we enable the citizens of Europe to benefit from the dynamic effects of a fully integrated common market with immense purchasing power...We must create the conditions in which European businessmen too can build on their strengths and create prosperity and jobs. This means action to harmonise standards and prevent their deliberate use as barriers to intra-Community trade; more rapid and better coordinated procedures; a major effort to improve mutual recognition of professional qualifications; and liberalising trade in services, including banking, insurance and transportation of good and people [...]".

Such was the importance Britain attached to the pamphlet that the British Ambassador in Bonn, Sir Julian Bullard, asked Chancellor Helmut Kohl's closest adviser, Horst Teltschik, whether there was anything in the British approach which the Germans found unacceptable or inadequate. Teltschik responded that the Germans found the British paper a very good starting point but Germany wanted not just to fulfil the existing Treaty, including by completing the single market, but to take a qualitative step forward in political union.

1. From 1979 to 1983, Stephen Wall served in the British Embassy in Washington. On return to the FCO he was Assistant Head and then Head of European Community Department (Internal). From 1988 to 1991, he was Private Secretary to three successive Foreign Secretaries (Geoffrey Howe, John Major and Douglas Hurd). From 1991 to 1993, he returned to $N^{\circ} 10$ Downing Street as Private Secretary to the Prime Minister, John Major, responsible for Foreign Policy and Defence. Stephen Wall served as British Ambassador to Portugal from 1993 to 1995. He was the Permanent Representative to the European Union from 1995-2000. From 2000-2004 he was the Head of the European Secretariat in the Cabinet Office in London and EU adviser to the Prime Minister, Tony Blair. He is currently the official historian for the Cabinet Office. In 2008, he wrote A Stranger in Europe, Britain and the EU from Thatcher to Blair, Oxford University Press, Oxford. 
At the same time, the British Embassy in Paris was reporting that the French government was attracted by the idea of European Union, especially if it was a vague concept that allowed them to exercise European leadership. That approach was not congenial to the British. In a speech in Bonn in October 1984, British Foreign Secretary Geoffrey Howe urged the need to make progress on trade, freedom of movement, environmental pollution and closer cooperation in foreign policy. He did not favour crossing "a paper desert of institutional schemes" but, instead, advocated making use of existing institutions to achieve pragmatic, flexible cooperation.

Margaret Thatcher put it more bluntly in an interview, in the same month, with a British newspaper. None of her partners could, she claimed, tell her what they meant by political union. Chancellor Kohl had called for a United States of Europe. She did not believe in that but in a Europe of separate countries coming together in a common market - a market which, in her view, the European Community was still a long way from achieving.

The Fontainebleau European Council had set up a committee, under an Irishman, Senator James Dooge, to make recommendations on the future development of the European Community. Despite British reservations, the Committee was looking at the need for Treaty change, including the completion of the single market. At a speech in Angers in November 1984, Thatcher told the Franco-British Council that she was against union and in favour of unity. She thought that the Community's founders would be horrified to see how their bold vision had been pinned down by bureaucratic regulations and how we had focussed on protecting home markets, not on expanding trade. Making a heartfelt plea for the kind of action she had called for in her pamphlet, she concluded by affirming Britain's desire for greater unity of Community action in world affairs, in tackling unemployment and in the development and application of new technology. That was her idea of a united Europe.

But, in the Dooge committee, the argument was slipping away from Britain. It was characteristic that, of the personal representatives of EC leaders who sat on the committee, Malcolm Rifkind, the Minister of State for Europe at the Foreign Office, was one of the few serving government members. Other heads of government had been content to appoint non-governmental personal representatives and to let a thousand flowers bloom, confident that they could take or leave the final product. That was not the British way, either then or since.

When the European Council met in March 1985, Thatcher was again clearly opposed to changing the treaties. In the view of the British government, the single market could be achieved on the basis of the existing Treaty of Rome, unamended. This view was almost universally held among ministers and government departments. Even the Foreign Office was slow to argue the case for majority voting to achieve Britain's aims and it took Rifkind to point out that,

"if we were serious about serving the British national interest through getting the single market completed, then we would probably stand to gain more than we would lose by votes being taken". 
Geoffrey Howe remained circumspect and the Prime Minister was firmly opposed. She told Commission President Jacques Delors in May 1985 that there was no need for Treaty change. In her view, if the European Community consumed its energies in trying to amend the Treaty, no practical work would get done. Foreign Secretary Howe, subsequently told Delors that the Treaty of Rome was the constitution of the European Community. It would be extremely difficult to change it since that required the assent of twelve governments and twelve parliaments.

The Prime Minister and Foreign Secretary went to the European Council in Milan at the end of June 1985 convinced that it was still possible to head off the demands for an inter-governmental conference to negotiate treaty change, not least because the European Council operated by consensus. But, in the event, Thatcher was outsmarted by Italian Prime Minister Bettino Craxi who rightly worked out that the decision to call an intergovernmental conference was a procedural one under the Treaty of Rome, requiring only a simple majority in the Council. Thatcher was outvoted and the conference was called.

Milan was a shock for the British. No one had seen it coming. Thatcher was used to using blocking tactics to secure success. On this occasion, her ace had been trumped. Britain still had a veto on the outcome of the inter-governmental conference, since any treaty change required unanimity. But Britain faced a choice between agreeing to some treaty change in order to secure the single market objectives of which she had been the main champion, or perhaps to face a situation in which her partners found a way to go ahead without her. This fear was very prominent in the minds of officials and does not seem to have been lost on the Prime Minister either. Even before she left Milan, she had accepted the advice of officials not to rule out all treaty change. She subsequently authorised British officials to negotiate on the treaty while reserving her position and saying that they did not know what position she would take in the end.

Thatcher's resistance to treaty change was not born of scepticism so much as a realistic assessment of British public and parliamentary opinion. Britain had been a reluctant European at the outset of the Common Market project. But the minds of senior ministers changed very swiftly after the signature of the Treaty of Rome and, had it not been for President Charles de Gaulle's veto of Britain's application in 1963, Britain would have joined by 1965 at the latest. De Gaulle's veto was a national humiliation, made even worse when he cast a second veto in 1967. British public opinion on Europe has never really recovered from that. Yet, it is now forgotten that when Prime Minister Harold Wilson re-launched Britain's bid for EEC membership in 1966, he secured the largest majority on any subject recorded in the House of Commons for over a century. And the British government of that day was open to the future political development of the EEC, including the prospect of economic and monetary union. Indeed, in the late autumn of 1966, Jim Callaghan, the Chancellor of the Exchequer, told a public meeting of City leaders that one answer to the perceived problems of the sterling area might be a single currency. 
After de Gaulle's loss of office in 1969, French official policy towards British entry into the EEC changed. But President Georges Pompidou, never an enthusiast for British membership, insisted that the definitive shape of the Common Agricultural Policy and of the EEC's own resources financing arrangements should be set before any renewed negotiations for entry were opened with Britain. Thus, France was able to secure arrangements which were uniquely favourable to her. And, having done so, the French government wrapped itself in the Community flag and insisted that no change could be made to what had now become Community practice. This was in sharp and cynical contrast to the attempts made by de Gaulle only a few years earlier to thwart the planned progress of the EEC towards more common policies. It was not the commonality of the policies that France objected to, but the extent to which they did or did not advantage France's national interests.

So the incoming Conservative government led by Edward Heath in 1970 was faced with two intractable problems: a British public opinion which had become hostile to the EEC because of de Gaulle's contemptuous intransigence; and financial arrangements which would put Britain at a huge financial disadvantage compared with her future partners and which, at French insistence, were un-negotiable. British officials advised Heath that, intolerable and unsustainable as these arrangements would be, to walk away from the negotiations would not be an answer. Britain could not prosper outside the EEC and would be forced back to the negotiating table in due course. At that point, Britain might be forced to accept an even harsher financial settlement.

In the end, therefore, Britain accepted a bad financial deal, but with a review clause. That review clause, invoked by the Labour governments of Harold Wilson and James Callaghan between 1974 and 1979, produced partial and inadequate rebates for Britain. But the underlying problem remained unresolved when Thatcher took office in 1979 and she was quickly persuaded by her officials that seeking a lasting solution must be her top European priority. To get the result which she eventually secured at Fontainebleau in 1984 required toughness and intransigence on her part given the fact that all of Britain's partners had a national financial interest in seeing Britain continue to subsidize their gains from the EEC budget. In accusing her of undermining the Community system, they were guilty, as she correctly saw it, of massive hypocrisy. Thus, once she had won the day, British public opinion generally and her own in particular, had again turned against Europe. She saw, in Treaty change, nothing but trouble within her own party and beyond.

When the negotiations on what became the Single European Act began, it was with huge difficulty that the British forbore from weighing in with their objections since the British government machine hates inaction, even when tactically driven, British negotiators sat on their hands in the early meetings of the inter-governmental conference. The tactic succeeded in that it smoked out the French and German governments and obliged them to reveal the very modest nature of the treaty changes which they (by contrast with the Commission, Italy and Benelux) wanted to achieve.

The inter-governmental conference which led to the Single European Act was the shortest in the history of the European Union to date even though the content of the 
eventual treaty was significant. As the December European Council under Luxembourg chairmanship approached, the principal British preoccupation was to constrain the wish of the European Commission to extend majority voting into areas such as taxation and workers' rights, to avoid extensions in the power of the European Parliament at the expense of national parliaments and the Council of Ministers, to avoid extending the definition of what was meant by freedom of movement and to ensure that majority voting did not weaken Britain's phyto-sanitary controls on imports of products such as plants and seeds. Curious as it now seems, this issue almost proved the deal breaker at Luxembourg.

The Prime Minister and Foreign Secretary were also concerned about the references in the draft treaty to economic and monetary union. But they felt obliged to accept what was written. First of all, the language harked back to the undertaking agreed to by Prime Minister Heath at the European summit of October 1972 ("the progressive realisation of Economic and Monetary Union"). Secondly, the relevant chapter of the Single European Act was headed "Co-operation in Economic and Monetary Policy (Economic and Monetary Union)", so the British could argue that economic and monetary union was a cooperative process, not a certain goal. And, finally, at a meeting with Kohl in the margins of the summit, the Chancellor reassured Thatcher that he was opposed to EMU, and that the text on the table was harmless and meaningless. The fact that further treaty change would be needed would, Kohl argued, be a protection against creeping EMU. Thatcher accepted those arguments.

In recent years, Margaret Thatcher has said that she was misled about the true nature of the Single European Act. At the time, she told David Williamson, then head of the Cabinet Office's European Secretariat, that she had read every word of the draft treaty and there was no question of her doing anything inadvertently. There were, however, two issues that were problematic for the British during and beyond the negotiation. The first was the definition of the Single Market in article 8A of the draft treaty. The internal market was to comprise

"an area without internal frontiers in which free movement of goods, persons, services and capital is ensured in accordance with the provisions of this Treaty".

Foreign Office lawyers believed that this wording and, in particular, the words "in accordance with the provisions of this Treaty" restricted the scope of free movement and did not imply free movement for all, in all circumstances. That view was supported by the Law Officers although, as I recall, they were not more than reasonably confident of the British case.

The European Commission never accepted the British interpretation and, as it transpired, nor did the European Court of Justice (ECJ) in subsequent jurisprudence. From 1986 to 1997, the British position was legally anomalous and successive British governments feared a challenge in the ECJ. In the end, the issue was resolved in the Amsterdam Treaty negotiations of 1997 in which Britain secured an "opt-out" from the EU's frontier-free provisions in exchange for allowing the terms of the Schengen protocol to be incorporated in the main EU Treaty. 
The second issue arose over article 21 of the Single European Act which required member states to "pay particular attention to encouraging improvements in the working environment, as regards the health and safety of workers, and [to] set as their objective the harmonisation of conditions in this area, while maintaining the improvements made". Qualified majority voting was to be introduced in this area but the directives in question were to establish "minimum requirements for gradual implementation, having regard to the conditions and technical rules obtaining in each of the member states". At British insistence the article also stipulated that "Such directives shall avoid imposing administrative, financial and legal constraints in a way which would hold back the creation and development of small and medium-sized undertakings".

Thatcher was not easily persuaded that this article was watertight from the perspective of a British government that did not want to see harmonising social legislation. British officials believed that the article was limited to measures related to health and safety. But, in practice, Thatcher's doubts were justified. The European Commission used the article as a basis of social legislation going beyond health and safety and, in doing so, was supported by a majority of other member states. The determined policy of the European Commission under Delors to create a social Europe going beyond anything which Thatcher had signed up to reinforce her view that the EEC was fundamentally protectionist. In this, she was of course, correct. Pompidou had told the editor of The Times in 1971 that he wanted the British to be in no doubt of the nature of the Community they were aspiring to join: it was protectionist and Britain had to accept that.

It had been his realisation that Britain would not accept a protectionist Community which had underlain de Gaulle's hostility to British accession. But, in resisting protectionism, and in canvassing for liberal economic policies, British governments were not simply pursuing national interest: Thatcher was more farsighted than many of her fellow heads of government in seeing the reality of a world in which the EEC was already losing competitive ground to the United States and Japan. The argument continues to this day.

At the end of 1985, Sir David Hannay, Britain's Permanent Representative to the European Communities, sent to the Foreign Secretary his annual review, a document sent to the Foreign Office by all its overseas posts, summarising the lessons of the year just past and making predictions and recommendations about the year to come. Hannay wrote:

"What at the time [the Milan European Council] looked like the possible beginning of a dangerous split in the Community, with the UK becoming isolated from the mainstream of Community policy making, has not turned out like that, not least because we ourselves set about preventing it from doing so. The maximalists (Italy, Belgium and Commission) in the event had little support and, above all, not that of France and Germany".

For Britain, something was won and something lost from the campaign for the Single Market. The gain was the priority given to the single market itself, something for which Thatcher can claim the principal credit among heads of government. It would 
not have happened without the commitment of Delors and the British Commissioner responsible, Lord Francis A. Cockfield. But nor would it have happened if she had not pressed the case, any more than the Lisbon agenda of economic reform would have happened without Tony Blair twenty years later.

What was lost from Thatcher's perspective was the ability to hold the rest of the European Community to ransom as she had done ruthlessly but necessarily over the British budget rebate. At Milan, Britain's partners found a way round her veto. That event sent shock waves through Whitehall. The possibility of being bypassed became a real fear and helped dictate the cooperative attitude shown by the British delegation in the subsequent negotiations on the Treaty itself.

Two years later, there was nearly a split between eleven member states and Britain over agricultural reform. In the event, both sides stepped back from the brink. A two tier Europe, much talked about at the time, did not happen. But the Europe of overlapping circles, also much debated, did start to happen. Its first formal manifestation was the Schengen agreement in which Five of the original Six decided to pre-empt wider Community agreement by abolishing frontier controls between them. Even at the time, it was obvious that this was a step of far reaching constitutional significance. What was less obvious at the time was the fact that the near split at Milan also changed the mindset of the European Community, not just in terms of better tactics by Britain's partners, but also in terms of a perception of a European agenda, set by France, Germany and the Commission, which other member states willingly bought into and to which Britain alone was perceived as the obstacle.

It would have been difficult, within the framework of the Treaty of Rome, for eleven member states to create a single market without Britain. When it came to the creation of a single currency in 1991, a treaty without Britain was much more attainable. Margaret Thatcher hated the idea but, had she survived in office she would almost certainly have been obliged to accept the opt-out/opt-in strategy that Major, her Chancellor of the Exchequer, was recommending to her and which he himself implemented when he became Prime Minister. That is not to say that her judgement was entirely wrong. Her Bruges speech of 1988 was seen at the time as an attack on the fundamentals of the European Community. Parts of it, in particular her call for the enlargement of the EEC, read today as both powerful and farsighted. Her strictures on a European Commission bent on the accretion of power at the centre, were cast in characteristically vehement form, but in substance she had a point. It was, after all, Delors who, soon thereafter, proposed a model of the EEC in which the Commission would be the government, answerable to the European Parliament and with the European Council as a revising chamber. What Margaret Thatcher said "no, no, no" to in 1990, the rest of the EU membership says no to it today. The European Commission president today would not even think to put forward such a model. Indeed, paradoxically, on issues such as climate change and energy policy, today's British government is more European-minded than its German, French or Italian counterparts.

The question whether Britain has paid a price for its opt-out strategy is beyond the scope of this paper. In both EMU and Justice and Home Affairs, Britain has the 
right to opt in and, in the latter instance, does so pretty consistently. In the case of EMU, the project itself has not been as economically or politically integrationist as Kohl and Mitterrand probably, and Delors certainly, envisaged. Indeed, today's European Union looks closer to the British concept than did the Europe of the 1980s, i.e. a Union in which political and economic integration happen organically more than by great institutional leaps forward. But that does not tell the whole story. In moving away from the approach of the constitutional treaty, the Lisbon Treaty has concentrated more on institutional changes necessary to attain practical ends. This applies, in particular, to the dismantling of the Maastricht pillar devoted to Justice and Home Affairs. The member states have decided that the extension of the Community method is necessary if they are to attain their shared objectives. This is exactly the approach which underlay the Single European Act twenty years ago. 


\title{
The Open Society and "British Soft Power" in Central/Eastern Europe at the End of Cold War
}

\author{
Carola CERAMI
}

In his book "Erasmians" Ralf Dahrendorf explored "the wellsprings of the liberal spirit". ${ }^{1}$ He focused on a generation of "public intellectuals" 2 born in the first decade of the $20^{\text {th }}$ Century, who grew up under the shadow of increasing Soviet power as well as the rise of Fascism and then of Nazism. In particular, he refers to three intellectuals: Isaiah Berlin, Raymond Aron and Karl Popper, calling them "Erasmians", because like Erasmus from Rotterdam, they were steadfast, under the most adverse conditions, in their adherence to core liberal ideas. Dahrendorf conferred the label of "Erasmian nation" on Great Britain, a country he considered to be immune from the temptations of authoritarianism and totalitarianism.

The "Erasmian" intellectuals cited by Dahrendorf played a leading role in the defence of the liberal spirit throughout the $20^{\text {th }}$ Century. This article will attempt to highlight the equally important role played by British intellectuals of Central European origins from a successive generation who were inspired by the Erasmians and committed to the liberalization of the Eastern European countries the 1980s and 1990s. Their engagement in this process is represented by the concrete application of their ideas on freedom and the Open Society.

As pointed out in the introduction, "in the second half of the 1980s Britain deployed a wider, more active and more effective Ostpolitik than at any time since the onset of the Cold War". ${ }^{3}$ This process was advantaged by the new climate of détente and had an extraordinary influence on East-West relations before the end of the Cold War. The "new détente" was also, as Mary Kaldor noted,

"a strategy of dialogue, an attempt to change society through the actions of citizens rather than governments, to change ideas and to develop new institutions; in short to create a new political culture". ${ }^{4}$

This article will analyse one specific aspect of cultural exchanges at the end of the Cold War in Europe, namely the influence of those intellectuals based in Great Britain who promoted a "strategy of dialogue" between intelligentsias on both sides of the

1. R. DAHRENDORF, Erasmiani. Gli intellettuali alla prova del totalitarismo, Editori Laterza, RomaBari, 2007 (title of the original edition: Versuchungen der Unfreiheit. Die Intellektuellen in Zeiten der Prüfung, Verlag C.H. Beck, München, 2006).

2. Dahrendorf's definition of "public intellectual" was the following: "We are not dealing with intellectuals in general, but with those whom I call public intellectuals [...]. The concept of public intellectual has a stronger meaning. These are people who believe it is an imperative of their profession to participate in the leading public debates of their time, indeed, to determine their contents and direct their development". See R. DAHRENDORF, Erasmiani ..., op.cit., p.14.

3. See the introduction to this issue.

4. M. KALDOR, G. HOLDEN, R. FALK, The New Détente. Rethinking East-West Relations, Verso, United Nation University, New York, 1989, p.15. 